\title{
FOLKLORE OF THE PEOPLES OF DAGESTAN
}

\author{
Aida Ruslanovna Gasharova
}

Department of Folklore, The G. Tsadasa Institute of Language, Literature and Art, Dagestan Federal Research Center of Russian Academy of Sciences, Russia.

Email: aida.2015@yandex.ru

\author{
Article History: Received on $1^{\text {st }}$ December 2020, Revised on $7^{\text {th }}$ July 2021, Published on $8^{\text {th }}$ July 2021
}

\begin{abstract}
Purpose: The article focuses on the genetic relationship of Dagestan people majority, which was reflected in the archaic layer of culture, on the processes of interethnic historical and cultural interrelations, which are generally characterized with a sufficient intensity in Dagestan.
\end{abstract}

Methodology: The article is a generalizing analysis of multinational Dagestan oral-poetic creativity, the statement of the positions and conclusions on the genesis and the centuries-old functioning of a unique folkloric unity in diversity.

Main Findings: Dagestan folklore material, in particular such genres as myths, legends, legends, heroic epic, heroic historical and historical songs and ballads, ritual poetry genres, unconscious lyrics, the fairy epics of its variety, parables, oral stories and anecdotes, proverbs, sayings and riddles are characterized by their commonality and mutual influences, conditioned by the historical and cultural interrelationships of Dagestan peoples.

Implications: Dagestan folklore material allows us to draw important conclusions concerning not only the peculiarities of the functioning of folklore in a particular region, but also the general theory of folklore.

Novelty: The very syncretic nature of folklore dictates the need for a complex attraction to the object of analysis of the verbal, musical, ethno-graphic and other components of this field of art, which makes it possible to more deeply and broader comprehend the above unity in diversity.

Keywords: Folklore, Peoples of Dagestan, Folklore Genres, Diversity, Convergence, Typology.

\section{INTRODUCTION}

Dagestan represents a unique region of Russian Federation both with respect to ethnic and linguistic diversity, and to a large extent the commonality of ethno specific features in culture. The ethnic composition of Dagestan population evolved historically, of course, but it remained roughly the same in the percentage ratio of ethos's to each other.

Dagestan peoples are the bearers of the Iberian-Caucasian, Turkic and Indo-European languages, while the mountain peoples of Dagestan have significant linguistic differences from each other. Each individual language is divided into dialects; there are even mono all languages. The peoples of Dagestan traditionally profess Islam, Christianity and Judaism.

Occupying a relatively small territory, Dagestan is geographically very diverse: a large part is occupied by mountains with the highest points within the Eastern Caucasus, a large area is also reserved for the fertile plain and semi-deserts, the republic is washed by the Caspian Sea from the east.

A relatively weak development of a nation genre is not only compensated by the more advanced genres of the same people, but also by other neighboring peoples, i.e. the folklore of Dagestan represents a single whole also in this respect.

There are a lot of factors playing a unifying role in the history, economy and culture of Dagestan peoples. During the archaic period of the history of Dagestan, in particular folklore period, the genetic affinity or relation of Dagestan tribes is significant, as was reflected in the data of archeology, ethnography, language, anthropology and folklore.

The multilingualism of Dagestan has conditioned the use of various languages as interethnic communication tools, as well as the stimulus for folklore mutual enrichment: the Azerbaijani language in Southern Dagestan, Kumyk - in the plains and the foothills of Central and Northern Dagestan, and also in a significant part of the North Caucasus, Avar - in the Mountains of Inner Dagestan (Arabic, Iranian, and later Russian languages in the traditional folklore process did not play an essential role).

It looks like that the folklore heritage of our time becomes a thing of the past, but the increased interest of different peoples to their ethnic-cultural origins, to their ethnic identity, has actualized its role, especially for small peoples. "The ambivalent role will play an important role in the fate of folklore, perhaps, of the entire ethnic culture of the 21st century evidently: on the one hand, new, practically limitless possibilities for folklore record appeared in all its diversity, in the syncretic unity of verbal, musical, choreographic and its other components, its multiple reproduction and broadcasting on a global scale: internet, television, etc.

Folklorists must take into account all this and to be guided by the demands of time in their further scientific activity. The ways of traditional oral and poetic creativity preservation and development should be the subject of a special wide discussion. 


\section{METHODOLOGY}

The very syncretic nature of folklore dictates the need for a comprehensive analysis of the verbal, musical, ethnographic and other components of this art in an object, which makes it possible to comprehend the above-noted unity in diversity deeper and broader.

The methods of research are determined by the specificity of Dagestan folklore, among which the main are the following ones: 1. historical and comparative; 2 . historical and typological; 3 . integrated.

The use of the first method was dictated by the fact that the scientific interpretation of an extraordinarily multiethnic and multilingual creativity of Dagestan, which at the same time represents a unique unity in diversity, is possible only with the use of a comparative historical method of analysis.

The historical-typological method of research in general is the most important in folklore, but in Dagestan it also acquires some specific features, which are primarily conditioned by a peculiar combination of the general typology processes with the regional (Dagestan) and zonal (Caucasian) one.

\section{RESEARCH}

The studies of folklore in Dagestan were mainly conducted on the basis of a specific ethnic principle in the writings by A.M. Adzhiev (Adzhiev, 2010), F.A. Alieva (Alieva, 2008), A.A. Akhlakov (Akhlakov, 2013), A.M. Ganieva (Ganieva, 1986), M.M. Kurbanov (Kurbanov, 1996), M.R. Khalidova (Khalidova, 1992), H.M. Khalilov (Khalilov, 2004a), although it should be noted that the the experiences of the general Daghestanian interpretation of the oral and poetic heritage of the peoples of Dagestan are also known (Abakarova et al., 1999; Adzhiev, 2005; Gamzatov, 2010; Ganieva, 2004; Gasanov, 1971; Dalgat, 1962; Russian song in Dagestan, 1975; Traditional folklore of the peoples of Dagestan, 1991; Khalidova M.R., 2004; Khalilov, 2004b). However, a large-scale, purposeful study and the publication of Dagestan multinational folklore as a kind of unity in diversity was initiated by the Department of IYALY DNTS of the Russian Academy of Sciences recently, which continues to this day (SPFND, V. 1, 2011; SPFND, V. 2, 2011; SPFND, V. 3, 2013; SPFND, V. 4, 2012; SPFND, V. 5, 2015; SPFND, V. 6, 2017; SPFND, V. 7, 2019).

Folklore ethnic specificity and interethnic community can be clearly traced in such genres as myths, legends, heroic epics, legends, heroic historical and historical songs and ballads, in calendar-ritual poetry, lyrical genres, non-ritual lyrics, fairy tales, parables, anecdotes and oral stories.

As is known, myths belong to the most ancient and typologically developed layer of folk art. As compared with the myths of other peoples of the North Caucasus, the general Dagestan specificity in Dagestan is the significant transformation of pagan mythology, a relative preservation of only the "lower mythology", which is obviously conditioned by an early adoption of monotheistic religions here (partly Christianity, later almost universally Islam, partially - Judaism). As is known, monotheistic religions strongly opposed pagan polytheism, idolatry, etc., on which, in particular, the heroic epic is based. At the same time, one can note the belief in Tengrianism among the relatively preserved domestic beliefs of the peoples of Dagestan (not only among the Turkic peoples of Dagestan, but as the echoes among the Avars and the peoples of Southern Dagestan); in a demonic being, in the guise of an ugly woman Al, Albasly, Albasti, Alpab and others (it is widely spread in Eurasia); in various deities, spirits related with the natural and cosmic objects, with the phenomena of nature (rain, wind), with the state of health (the spirits of disease); the presence of twin etiological plots and many other factors.

It should be noted that in connection with the adoption of Islam, the commonality among the majority of Dagestan peoples can be traced in borrowed Quranic plots, Muslim legends, sometimes layered on local plots. The legends are very close to the mythological genres of folklore of the peoples of Dagestan, i.e. the things noted above with respect to mythological genres, their national specifics, interethnic community and typological convergence, can be attributed to mythological legends in a certain extent.

Traditions also often come close to legends, however, as a rule, they are associated with local historical events, therefore, with all the use of general types of plots, motifs and images, they have more ethno specifics. In general, the legends about the struggle against foreigners (Arabs, Mongols, the hordes of Tamerlane, Nadir Shah, the Caucasian War, the uprising of 1877 , the revolution and civil war, the Great Patriotic War, etc.) are the common ones for Dagestan. However, with all this there are the texts, both single-national and common ones only for a few peoples, which give a unique picture of unity in diversity in this genre (Abakarova et al., 1999: pp. 178-197; Adzhiev, 2005; Alieva, 2008: pp. 157-232; Ganieva, 2004: pp. 170-207; Dalgat, 1962: pp. 109-151; Kurbanov, 1996: pp. 127-171; Traditional folklore of the peoples of Dagestan, 1991: pp. 290-322; Khalidova, 1992: pp. 193-269; Khalidova, 2004: pp. 55-95; Khalilov, 2004b: pp. 252-256; Edige, 2016).

There is a lot of ethnic originality in the heroic epic of the peoples of Dagestan especially. Some Dagestan people have the monuments of the Nart epic, bringing this area of creativity closer to the traditions of many other peoples of the Caucasus, but in general archaic monuments, especially songs, which can be attributed to the heroic epos, are represented poorly in Dagestan now, which, apparently, is primarily due to the early destruction or the transformation of heroic epic mythological foundations. 
The Lezgin had folklore about Sharvili, but it is represented in different genres: in legends, often going back to ancient times, in lamentations, quatrains, etc., and associated with the events, starting from antiquity to the period of the Great Patriotic War. Despite the ancient origins of a number of motifs, the fundamental Nogai epic "Edige" (Edige. Nogai epic, 2016) belongs to the Middle Ages, and it was quite widespread among other Turkic peoples (Kazakhs, Karakalpaks, Tatars and others.), and in Dagestan among Kumyks, partly among Dargins, i.e. representing the Turkic traditions in general, it enriches the multinational palette of Dagestan folklore in its own way.

The next stage layer of epic poetry of the peoples of Dagestan - the heroic-historical and historical songs - got a strong development.

A ballad is at the turn of historical song and lyrics genre. (Abakarova et al., 1999: pp. 90-98; Adzhiev, 2005: pp. 59-69; SPFND, V. 5, 2015; Dalgat, 1962, pp. 109-127; Kurbanov, 1996, pp. 52-88; Traditional folklore of the peoples of Dagestan, 1991: pp. 96-123; Khalidova, 2004: pp. 217-236; Khalilov, 2004b: pp. 113-129). It is interesting that this genre specificity (lyric-epic genre) in the ethnic plan as a whole is consistent with the peculiarity of epic and lyrical poetry development among different peoples of Dagestan. Among the peoples of Southern Dagestan, which, as was noted above, the song story is poorly developed. There are no ballads here in the classical sense of the genre. The ballad songs with the prevalence of lyricism (lamentations, love songs, quatrains - maniar, maily, bend, etc.) were developed here strongly. Among Dargins, whose folklore received a strong development of the lyrics, but as compared with other peoples of Dagestan living north traditionally, the heroic and the epic song were less developed. Ballad developed greatly and naturally, and the plots of heroic and historical songs common to several peoples of Dagestan became "ballad like". Heroic patriotic epic and lyrical genres are especially developed among Kumyks.

In the lyrical genres of oral-poetic creativity of the peoples of Dagestan, the interethnic and ethno specific features are not subject to sufficiently pronounced regularities at first glance, they look like chaotically "scattered" in a large array of folklore. Indeed, the lyric poetry, as an area of artistic creativity, turned, first of all, to almost unlimitedly diverse and subtle inner world of a man, is difficult to "structure" and then to systematize these structures. However, of course, this does not mean that the lyrics do not obey any typological laws of evolution, in particular, the natural manifestation of genre and ethnic processes in it. In the stadially archaic ritual poetry we observe the origins of these processes. In calendar-ritual poetry, the national-specific features are more evident among small peoples, as well as in the details of the ceremonies, in their names, however, the time of performance, the main features, the participants of festivities are common in general among all the peoples of Dagestan, and are often interrelated. Family-ritual poetry is divided into wedding and funeral poetry.

Non-ceremonial lyrics largely continue its traditions ritual poetry. However, it is much more difficult to draw a fairly clear line between genres and mainly national traditions. The song lyrics of the Russian population in Dagestan preserve the common Russian traditions, but it is interesting that in this ethno-stable field of folk art, the Caucasian elements choruses, themes, vocabulary, etc. are included (Adzhiev, 2010: pp. 83-98; Russian song in Dagestan, 1975).

In connection with a particularly well-developed typology of the fairytale epic (the fairy tales about animals, fairy tales, everyday fairy tales), it is difficult to single out the texts created by this or that specific people in these genres, especially since the regional typology is also manifested in Dagestan. Typologically common, and often very ethnic-scientific fairy-tale formulas, motives, plot interpretations, etc. are of a special interest. The features of ethnic origin noted above, with certain adjustments to genre specificities in general, can also be attributed to parables, oral stories and anecdotes.

To a certain extent this can also be attributed to the genre of riddles, proverbs and sayings.

\section{CONCLUSIONS}

Thus, the article shows the nationally specific and national in the folklore of the peoples of Dagestan, their systemic interconnection, historical evolution, which are of great importance both in the scientific comprehension of the Dagestan unique material specifically, so maybe for the elaboration or refining and the correction of some theoretical provisions of folklore.

Dagestan folklore material makes it possible to draw important conclusions concerning not only the features of folklore functioning in a particular region, but in some cases also the general theory of folklore. Despite some differences in the geographic, socio-economic and cultural development of individual micro-regions, the peoples of Dagestan lived a single historical and cultural life, which predetermined the typological commonality of both individual genres and many genre varieties.

\section{REFERENCES}

1. Abakarova, F. O., Alieva, F. A. (1999). Essays on the oral and poetic creativity of the Dargins. IALY DNTS RAS, $258 \mathrm{p}$.

2. Adzhiev, A. M. (2005). Oral folk art of Kumyks. IALY DNTS RAS, 427 p.

3. Adzhiev, A. M. (2010). The problems of the Dagestan and North Caucasian philology in the context of a dialogue of cultures and times. IALY DNTS RAS, $360 \mathrm{p}$. 
4. Akhlakov, A. A. (2013). Historical songs of the peoples of Dagestan and the North Caucasus. IALY DNTS RAS, $244 \mathrm{p}$.

5. Alieva, F. A. (2008). Interrelations of oral prose genres in the folklore of the peoples of Dagestan. IALY DNTS RAS, 364 p.

6. Dalgat, U. B. (1962). Folklore and literature of the peoples of Dagestan. Oriental literature, 207 p.

7. Edige. Nogai epic poem. Nauka, 2016. 512 p.

8. Gamzatov, G. G. (2010). Folklore: a measure of historicism. Science DNTS, 370 p.

9. Ganieva, A. M. (1986). In search of a legendary hero. $150 \mathrm{p}$.

10. Ganieva, A. M. (2004). The essays on the oral and poetic creativity of the Lezgins. Ed. in charge G.G. Gasharov. Nauka, 239 p.

11. Gasanov, M. M. (1971). Daghestan folk proverbs, sayingsand puzzles. Daguchpedgiz, 78 p.

12. Khalidova, M. R. (1992). Mythological and historical epic of the peoples of Dagestan. IALY DNTS RAS, 275 p.

13. Khalidova, M. R. (2004). Oral folklore of Avars. IALY DNTS RAS, 335 p.

14. Khalilov, Kh. M. (2004a). The lyrics of the peoples of Dagestan: interrelations, typology and ethnic specificity. IALY DNTS RAS, 2004. 294 p.

15. Khalilov, Kh. M. (2004b). Oral folk art of the Laks. IALY DNTS RAS, 324 p.

16. Kurbanov, M. M. (1996). People's soul and memory: Genre specificity of the Tabasaran folklore and its historical evolution. Dagknigoizdat, $224 \mathrm{p}$.

17. Russian song in Dagestan (From the records of 1964-69). Publication, entry article and comments by V.S. Kiryukhin. 1975. $261 \mathrm{p}$.

18. The collection of folklore monuments from the peoples of Dagestan: in 20 volumes. V. 1. Tales of animals. Ed. by the acad. G. G. Gamzatov; Institute of Language, Literature and Art named after G. Tsadasy DNTS RAS. Nauka, 2011. 378 p.

19. The collection of folklore monuments from the peoples of Dagestan: in 20 volumes. V. 2. Fairy tales. Ed. by the acad. G.G. Gamzatov; Institute of Language, Literature and Art named after G. Tsadasy DNTS RAS. Nauka, 2011. $653 \mathrm{p}$.

20. The collection of folklore monuments from the peoples of Dagestan: in 20 volumes. V. 3. Home tales. Ed. by the acad. G.G. Gamzatov; Institute of Language, Literature and Art named after G. Tsadasy DNTS RAS. Nauka, 2013. $566 \mathrm{p}$.

21. The collection of folklore monuments from the peoples of Dagestan: in 20 volumes. V. 4. Mythological Prose. Ed. by the acad. G.G. Gamzatov; Institute of Language, Literature and Art named after G. Tsadasy DNTS RAS. Nauka, 2012. 294 p.

22. The collection of folklore monuments from the peoples of Dagestan: in 20 volumes. V. 5. Heroic and heroichistorical epic. Ed. by prof. M.I. Magomedov; Institute of Language, Literature and Art named after G. Tsadasy DNTS RAS. Nauka, 2015. 588 p.

23. The collection of folklore monuments from the peoples of Dagestan: in 20 volumes. V. 6. Ritual poetry. Ed. by prof. M.I. Magomedov; Institute of Language, Literature and Art named after G. Tsadasa DSC RAS. Nauka, 2017. 679 p.

24. The collection of folklore monuments from the peoples of Dagestan: in 20 volumes. V. 7. Children's folklore. Ed. by A.T. Akamov; Institute of Language, Literature and Art named after G. Tsadasa DSRC RAS. Alef Publ., 2019. 509 p.

25. Traditional folklore of Dagestan peoples. Nauka, 1991. $496 \mathrm{p}$. 